\title{
The Managerial Perspective and Systems of Accountability in Judicial Offices
}

\author{
Ubaldo Comite
}

Additional information is available at the end of the chapter

http://dx.doi.org/10.5772/67555

\begin{abstract}
In Italy, the machinery of justice has been, on more than one occasion, the subject of criticism. For the most part, the criticism has been relative to the slowness of trials and the inadequacy of the judicial system, deemed not capable of confronting the request for continuously evolving justice in an exhaustive manner, whose characteristics change in time based on the emerging needs of society. The analysis of the justice system was, in fact, generally not subject to enquiries on offices' productivity and to evaluation of the management of resources invested in the sector. The same centres of data elaboration and the related departments at the Ministry of Justice, for example, have not gone much further than collecting the statistical data and creating the generic indicators of service quality. Such parameters, though, are often revealed to be too bureaucratic and of little use in proposing ameliorative solutions of the service offered to citizens, who desire levels of protection that are more responsive to their expectations. In this sense, the application of the system of accountability within the judicial system can contribute to the managerialization of the service.
\end{abstract}

Keywords: judicial administration, business, accountability, Ministry of Justice, service

\section{Introduction}

An efficient and effective operation of the judicial system in which a request put forward by the citizens and an offer from the judicial institution represents one of the indispensable conditions for promoting and guaranteeing the proper operation of an economic and social system [1].

At first glance, the use of the criteria of efficiency, effectiveness and economy, which are typical economic business parameters in the study of the operations carried out by the courts, can be surprising. 
The analysis of the justice system was, in fact, generally not subject to inquiries on offices productivity and to evaluations of the management of resources invested in the sector [2].

The same centres of data elaboration and the related departments at the Ministry of Justice, for example, have not gone much further than collecting the statistical data and creating the generic indicators of service quality. Such parameters, though, are often revealed to be too bureaucratic and of little use in proposing ameliorative solutions of the service offered to citizens, who desire levels of protection that are more responsive to their expectations.

Not infrequently one speaks of inefficiency in the justice sector as well as of the excessive delays in proceedings which are required to give replies to public and private interest derived from the acknowledgement of the interests recognized in court. Usually, however, the support of the considerations expressed is omitted with a suitable analytical technique to formulate corrective solutions. Instead, the attempt to apply criteria typical of the economic business analysis to the study of trials (civil and criminal) and to the organization of judicial offices could prove useful [3].

The observation of the offices and the concrete verification of the organization of the solutions adoptable for improving it would become, therefore, useful instruments with which to study reality, even if it is as complex as the courts.

Only if the reasons that determine a disadvantageous or a crisis situation are known can there be an intervention in some form to orient it, considering the judicial organization as a single productive unit that aims to maximize the beneficiary who could draw from the resources available (thus reaching the efficiency of the office itself or through a more parsimonious use of at least one input, for the same output, or through the increase of the amount of output, for the same input) [4].

In view of the progress achieved by other sectors in public administration, where the application of economic business criteria has registered considerable results in terms of the optimization of resources and good performance of the service (local health-care authorities, local authorities, universities, chambers of commerce, etc.), virtually as much concreteness is not found within the justice system. This environment, in fact, has always drawn out objective problems of conceptual order connected, first of all, to the difficulty of reaching a definition that is not contrary to the judicial function itself (or jurisdictional) and secondly to the particular nature of the principles and values involved. Repression of crime, sense of safety and legality, substantial equality for all citizens before the law, presumption of innocence until tried, reasonable length of trial, guarantee of defence for the defendant, judicial protection for victims, and separation of power are some of the values for which only effectiveness is looked at, instead of implementing them in an efficient manner [5].

This has produced, not infrequently, a result conversant with measures and provisions that are neither effective nor efficient.

The judiciary organization, as a whole, and singularly of all those who operate within it (clerks, public ministers and judges, civil or defence lawyers, witnesses or consultants, assessors and judicial officials, investigative police, etc.) uses considerable resources in carrying out the proper functions [6]. 
It is often from the resource entities themselves who choose to assign one activity rather than another on which the outcome of the action plan depends; just as it is from the entity and the nature of the resources available that certain strategic choice can depend. Each strategic option, in fact, has a cost that is also represented by the alternative that is renounced in order to go with preferences, and even the choice between different procedural stances must be studied on the base of cost opportunity that each determines.

To this logic, one certainly cannot take away anyone involved in the judicial sector, but without a doubt nor does it take away the legislators, who must face budget constraints, problems connected with the managerialization of the service and with the costs and opportunities of each policy [7].

\section{Public administration and corporatization}

The definition of new functions, services and development strategies of which public administrations are recipients (id est judicial administrations) necessitates a reflection in regard to the process of corporatization of public administration [8].

The starting point of the important changes that have interested public administration in the last few years is made up of reform processes that can be defined 'as explicit modifications of the operating rules of the systems' [9]. A positive change of a determined situation is implicit in the achievement of these reforms. With reference to public administrations, the necessity to carry out these transformations emerges from various motivations, traceable to a gap that was progressively growing between what public administration should have done from an institutional point of view and what it actually did do, in view of an always greater quantity of resources absorbed.

In short, reform functions as a factor that produces, promotes or facilitates change, in that the system that is the subject of the reform manifests a motion of development that is inferior in respect to that necessary. The regulation consists of a fundamental passage to institutionally accredit innovation in planning and oversight functions and the introduction of new organizational and managerial instruments.

Public administration, besides Administrative Law, has for a number of years been considered a subject in Business Administration, a discipline that puts into practice a unified study with the theme of economic activity, independently from the nature of those involved in its practice, from its dimensional characteristics or from its legal background.

Even in public administration, in fact, all those requisites of Business Administration that qualify a business are recognized. These are autonomy, continuity, dynamism and coordination, reason for being and social legitimization to be constantly achieved in the interaction with the environment.

Autonomy of a business intends its ability of self-determination. This requirement allows business activities to be distinguished from all the economic activities conducted within an 
institution, but bound by a relationship of accessoriness. Speaking of autonomy, it is also necessary to recall its three main specifications. One speaks, in fact, of decision-making autonomy, which is the ability of self-legislation, of choosing conduct and behavioural guidelines; of asset autonomy, such as conditions of self-determination in economic choices in the administration of its own resources; finally, of economic autonomy, such as the power to control the flow of resources that characterize carrying out the activity of management [10].

It can be absolutely agreed upon that all three of the specifications indicated belong to the public context. To safeguard these forms of autonomy, the Law itself and the Constitution are in place.

The second aspect, continuity, manages to translate the necessary continuity of existence of the public authorities foreseen in different constitutional and administrative ordinances into economic-business terms. If on the one side there is a necessity for continuity for legal and political motives, on the other side, a balance that allows for the correct economic and financial survival of these authorities should be necessarily guaranteed.

It is, therefore, a continuity that is characterized by dynamism and subject to evolutionary phenomena and adaption (coordination) to the requests of the service users.

The reason of being and the social legitimization of the public authority, furthermore, are phenomena that do not lend themselves to particular objections, from the moment that they find their origins not only in the law but also in the social contract of a country [11].

So, if the public authority takes on all the characteristics typical of a business, it is a business itself, and, as such, can be studied in a homogeneous manner, prescinding from characteristics of form that distinguish the typologies.

Moreover, discussing public businesses only means putting together two terms of a diverse nature: the first is of a business origin, the second of a judicial origin.

Business [12] is a typical concept of Business Administration that answers the theoretical constructions and the relative operative indications, while public is the qualification that represents a particular mode of being of the business phenomenon.

This allows for the public authority (administration) to be put into a framework as a business equipped with specificities and, as such, characterized by communal rules independently of its dimensional, organizational or regulative characteristics.

Its process of administration and control becomes, therefore, identifiable with that of an activity with all the typical connotations of a business, with respect to the principles and laws of Business Administration.

All this brings about the recognition of two different operating dimensions within public administration:

- a political dimension, adopted in a determined moment and in a determined space by institutional bodies and by logic that controls the operation of economic governance, within which the interpretations of the aims of the authority are expressed and where the concept of the institution itself is explicated; 
- a business dimension through which the carrying out of the operations of production and consumption, as well as administration of the assets are assured.

For this reason, it is necessary to classify the various authorities of public administration based on the different relationships between the two dimensions and the different contributions that they variably will give in time to the achievement of the primary aims, analysing the so-called level of corporativity that it characterizes, in other words, the role that the objectives take on in an economic business nature in which they reside.

The presence of such different levels will depend on two factors:

- a political-institutional factor, that is, the choices that the Legislator has made on these types of authorities and the degree of financial and proprietary autonomy that each will recognize;

- a factor pertaining to the economic situation, that is, the economic-financial characteristics of a single entity and the needs that they set down [13].

Corporatization has the objective of bringing the essential and indispensable qualities of private companies into any public enterprise. Amongst them, these play a primary role: (1) the decision-making autonomy and the correlated taking on of responsibility for the decisions made, as well as for the results attained, (2) the effectiveness, efficiency and economy of management and (3) the professionalism of the managers and the workers and the formation of a corporate culture.

The terms effectiveness, efficiency and economy are keywords in the economic-business dictionary; it is not by chance that the search for such conditions is communal and indispensable objectives for all enterprises. A brief description would be that effectiveness identifies the capacity to reach set objectives, efficiency is that of reaching a given goal with the minimum waste (optimizing, namely, the use of resources and therefore improving the input-output relationship), economy identifies a situation of balanced and complete valorization of the economic, organizational and professional resources of a company.

Within the process of corporatization, the concept of effectiveness is tied to that of the quality of services. The public enterprise carries out its activities at an advantage over other enterprises of singles users or groups, to each of which it must assure the satisfaction of the needs expressed. Contemporarily, such enterprises must also commit themselves to the achievement of technical and economic efficiency, namely reaching their managerial goals by reducing the degree of the means used and, compatibly with its size, the level of costs.

While the considerations expressed above on the concepts of effectiveness and efficiency are valid for both private enterprises and public, there are some differences for economy. Indubitably, reaching a balance that has value over time is an indispensable objective for all enterprises on par with that of effectiveness; however, from the public characterization of the economic subject and with the aims of general socio-economic interest pursued, they carry constraints and requests that are different in respect to private enterprises which, in fact, can limit their profitability in a brief period. 
Nevertheless, the actions of public enterprises must always be brought back to the principles of maximum efficiency, economic rationality and the achievement of the conditions necessary for economic self-sufficiency as well as global and total quality.

In summary, the public admiration-business system relationship develops through the reestablishment, or the introduction, of the managerial perspective, which in turn is based on (a) the search for consonance amongst the aims, the objectives and the constraints, in order to guarantee the unity of the management, (b) the adoption of a strategic perspective, which combines long-term needs with those derived from everyday management which then contributes to guaranteeing a lasting operation of the organization and (c) the orientation towards effectiveness, efficiency and economy (Figure 1).

For this reason, for more than two decades by now, institutional, regulative and managerial reforms are significantly modifying the face of public administration, pushing to be closer to citizens and for better quality of the services offered. This sometimes entails the redesign of institutional structuring and calls for innovative organizational models to respond to new demand.

Therefore, the path to reform undertaken by public administration has tried to outline a new 'public administration model' oriented towards understanding the principles of 'business management' [14].

In this context, the planning of the activity of direction and guidance of the entire system can be seen, or rather the activity through which the objectives of their own actions as a 'business' are identified and decided, activating adequate and correct decisions capable of reaching the set objectives in the execution phases.

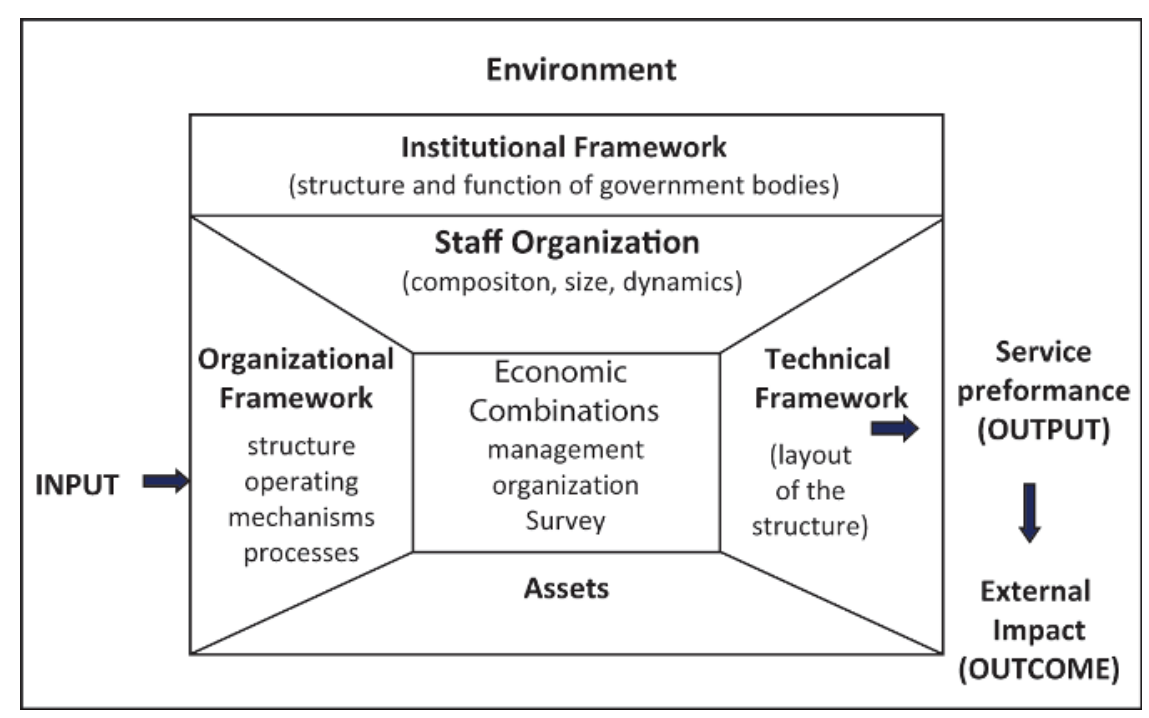

Figure 1. The dynamic system of public administrations. Source: personal elaboration. 
Consequently, the activity of control consistent in the survey, analysis and valuation of the results obtained and of the connection between these and the set objectives or decisions of the enterprise bodies appears of undeniable relevance.

In this direction, legislation has done much, forming an unavoidable constraint which must be necessarily taken into consideration, essentially looking towards the aims indicated by the legislator without, though, creating a 'regulative guide' [15].

The business paradigm, even if it intervened late in offering its contribution to the study of public administrations, represents a third dimension, alongside political and institutional, that guides the behaviour of public businesses in the pursuit of their own institutional goals. The consensus and the legitimization on the part of the stakeholders cannot prescind from the ability of the public business [16] to operate according to the principles of economic rationality and, in particular, that of economy [17].

In this sense, the authority of the resources absorbed by the public sector, the extent of the tasks and the competences entrusted to them impose the daily confrontation, upon political, economic and administrative players, scholars and researchers, with a managerial approach, of problems connected to efficiency, effectiveness and economy of the administrative acts and of management that characterize the daily behaviour of even judicial administrations.

\section{Judicial administration and managerial perspectives}

A new paradigm has imposed itself onto judicial administration: obtaining and managing consent both externally, by obtaining the trust of the stakeholders, and internally, through values that can consolidate the various organizational levels.

In light of the considerations carried out, it is possible to identify certain criteria that in substance reconnects itself to the principles of business economy and that in their organic whole make up a system of 'values', which by integrating themselves into the operative plan and if knowingly made up of all the institutional participants (stakeholders) are capable of obtaining, in an economic-business and managerial sense, judicial administrative management.

Schematically, the previously mentioned system of values refers to the following concepts [18]:

- economy of management: as the judicial system is an economic 'institute' with the purpose of enduring in time, economy of management is placed at the apex, meaning that its operations must be based on criteria of 'economy' geared towards results. Here, as opposed to the enterprise that produces for the market, economy is not measured by profit, but rather by utility, which is reached by 'efficiently' producing goods and services which are capable of 'effectively' satisfying the needs of the citizen user. This means that in judicial administration, the quantification of results, which cannot be entrusted towards a sole indicator of profit, is reached for in other indicators that are different based on the type of production of goods or services, entrusting the budget specifications to a model that, in respect to the conditions of efficiency and effectiveness [19], can concretely inform the entire business 
activity, focalizing attention on reengineering and on simplification, with the objective of reducing waste, re-thinking and re-inventing the so-called Judicial Government, with the intent to increasing the effectiveness of the services.

- planning and oversight: these two elements make up an essential value in judicial administration, in that planning allows for, on the one side, the rationalization of the behaviour of the 'deciders' and, on the other side, the defining of the model capable of stabilizing the economic conditions that must guide the business activity. Oversight allows for the verification of the manner and measure that the economic conditions are realized in the effective carrying out of the business management.

- the information system: intended as an interrelated whole of elements, it attributes operational concreteness to planning and oversight, in that it allows the identification, through the handling of information, of the parameter of economy, offering a base, as objective and rationale as possible, to the management of the business. The managerial data acquire economic and juridical value, thus becoming information, only if they are properly organized and actually used in the decision-making processes in relation to their identification abilities.

It is a shift from the exclusive use of top-down-type logic promoted by the 'centre' through laws that reward and punishment systems could be associated, to bottom-up-type logic characterized by voluntary experimentation on part of single tribunals and by the subsequent diffusion in the public administration system of the emergent models. Consolidating, therefore, the action coordinated between the policies of support promoted on a central level and the promotion and diffusion from the bottom of innovative experiences and best practices, such as good-quality projects, innovation rewards and the systematic benchmarking of results and processes.

- the organizational culture: it interests above all the valorization of human resources, the personal qualification of the managers, the involvement of the staff, who must be made responsible for the expected results. The process of gradual re-orientation of the staff towards the business values, which in the general public are more difficult to learn, often reducing itself to mere formal acts, entails a symmetrical and equally gradual overcoming of the typical bureaucratic-administrative culture (government), characterized by exclusively juridical knowledge, oriented towards the oversight of the acts more than the results, fraught with formal responsibility in the direction of respecting the regulations as such without the due attention for the results that the same regulation aims to achieve (governance), without stimuli in the direction of change imposed by the constant reform of public administration.

- social control and the ethical dimension: the first value permeates judicial administration from the political-social point of view, as it is exercised by the people interested in the business itself, that is, the citizen users, or by who represents them, that is, the determined body (Ministry of Justice, magistrates). The ethical dimension, instead, re-enforces social control in the sense that the economic rationality and the ethical values in operating in the public administration are complementary aspects of a single 'system of values', adopted as a model of operation of the judicial administration, founded on values that are necessarily both ethical and economical [20]. 
The whole of these values outlines a virtuous cycle capable of distinguishing the actions of the judicial administration [21].

\section{Judicial accountability and its application}

Accountability in public administration proposes a report that is geared not only towards a higher-level public body, a monitoring body or, generically, to the administrative community, but also to all the principle categories of stakeholders, in the knowledge that all are interested in the business activity, or benefit from the results, and furthermore that all, with their active and reactive behaviour, have the ability to influence the activity itself, collaborating positively, or posing obstacles which would hinder the possibility of the business reaching their planned objectives [22].

The concept of accountability is considered as one of basic principles in the process of change and reform in public administrations that, even in an Italian context where it has not found a specific translation, it has been interpreted in its acceptance of attitudes of being accountable, of transparency and responsibility, distinguishing the aims and the external or internal focus to the business [23].

Despite the proliferation of definitions proposed on the concept of accountability, they seem to be accumulated:

1. from the greater complexity of the contextualized concept in the public sector in respect to its application in the private sphere;

2. from necessity, in order to speak about accountability, of the presence on one part (accountee) that must wait for another (accountor), responsible for accounting for how to respond to the same.

Specifically, the concept of accountability in judicial offices requires a transfer of information from the accountor (judicial office) to the accountee (citizen, political body, etc.) to whom the possibility of assessment of the public action based on the information obtained is recognized [24].

It can be stated that the aim is to create a 'relationship' between public administration and general stakeholders (stakeholder relationship), through a process of one-to-one communication (Figure 2).

In particular, in order to speak of judicial accountability, not only is the availability of information a necessity but they must also have the characteristics of reliability, comprehension, accessibility, diffusion and distribution.

Finally, the process of accountability must foresee the possible judgement expressed by the accountee that represents feedback on the part of who receives the information towards who sends it. 


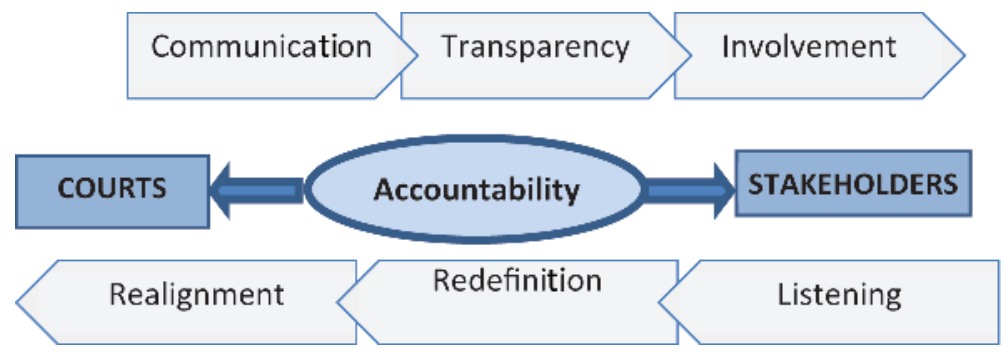

Figure 2. Relationship management with stakeholders. Source: personal elaboration.

In merit of the focus that addresses the process of accountability, a relevant distinction is highlighted among

a) an external orientation. In this case, the judicial offices should demonstrate that they are accountable, assuming responsibility for their actions and the results obtained, communicating them to the stakeholders, denoting transparency on the acquisition and the use of resources and on the performance achieved;

b) an internal orientation. In this hypothesis, accountability has a value as internal decisionmaking support entailing utility towards managers and magistrates. This would allow these figures to assume responsibility in a conscious manner, acquiring greater awareness about the objectives to be reached and regarding the necessity of accounting for the choices made and the results reached.

In order to better illustrate the different dimensions that can assume responsibility in judicial offices, it can be useful to consider a matrix analysis model composed of two principle dimensions of analysis (Table 1): (a) the recipient of accountability (internal or external) and (b) the type of results on which accountability is founded (financial-economical or meta-economical).

As it can be easily inferred from this model, accountability applied to judicial offices appears as a complex concept characterized by numerous aspects. In an environment with 'the need to account', in fact, a multitude of functions and tasks are included.

In other words, therefore, the manner with which judicial administration 'accounts' to the citizens can be varied.

As has happened for various types of public administration, even for judicial offices, the evident gap created in the years between user expectation and the services actually delivered has contributed to raise awareness of the nature of public service, which must be delivered with efficiency and economy.

The need for reform processes that are capable, on one hand, of developing a greater consistency between demand and supply of the services, and, on the other hand, of favouring the recovery of administrative action transparency and of the oversight on behalf of all the stakeholders is thus rendered evident. 


\begin{tabular}{|c|c|c|}
\hline & Financial-economic dimension & Social dimension \\
\hline Internal accountability & $\begin{array}{l}\text { Function } \\
\text { Taking responsibility for the } \\
\text { financial-economic results and the } \\
\text { articulation of authority costs } \\
\text { Instruments } \\
\text { Oversight of management, ABC, } \\
\text { remuneration tied to performance, } \\
\text { etc. }\end{array}$ & $\begin{array}{l}\text { Function } \\
\text { Taking internal responsibility for the } \\
\text { strategic objectives } \\
\text { Instruments } \\
\text { Balanced score card, MBO, etc. }\end{array}$ \\
\hline External accountability & $\begin{array}{l}\text { Function } \\
\text { Accountability and representation } \\
\text { of costs and income of a financial } \\
\text { nature } \\
\text { Instruments } \\
\text { Financial accounting }\end{array}$ & $\begin{array}{l}\text { Function } \\
\text { Accountability and representation of } \\
\text { effectiveness, social impact and mission } \\
\text { consistency } \\
\text { Instruments } \\
\text { Social balance }\end{array}$ \\
\hline
\end{tabular}

Source: modified by F. Monteduro (Ed.) Amministrazione Pubbliche: principi e sistemi contabili. Aracne, Rome, 2006.

Table 1. The dimensions of judicial accountability.

In other words, an evident need for new governance mechanisms and accountability logic in judicial offices that are compatible with the independence of the magistrature was created.

Intended in terms of taking on responsibility, as well as reporting accounts, accountability represents, therefore, a necessity in the public sector in general, and in the judicial system in particular.

Anywhere resources are used in order to guarantee the attainment of a result, be it of public interest, or in the interest of a few, there is the need to take on responsibility for the results and accounting for them, to verity if, and in what way, the awaited results were met.

From the above-mentioned considerations emerge, therefore, the particular significance of the process of accountability in judicial offices.

If, in fact, transparency and reporting accounts through methods that go beyond those imposed by law are useful for enterprises and can produce important benefits for them (trust, image, shares, etc.), for judicial office it is a duty towards the recipients of the accountability process, in respect to the purpose of collective interest of this type of 'business' and the relationship of trust on which their actions are based, namely, as the need for reporting accounts and taking on responsibility not only for the efficient use of resources but also for the result obtained in terms of output and outcome.

\section{Conclusion}

The attempt of adopting a managerial logic in the judicial sector is certainly more complex because the service rendered by the courts is characterized by publicity and by specific needs and rules that make it more peculiar. 
It is this character, however, that renders worthwhile each analytical attempt that aims to obtain a higher and higher level of satisfaction for the user.

Despite the evident need, the diffusion in the judicial offices (and therefore the same throughout the judicial system) of accountability logic and managerial orientation that could promote the recovery of higher levels of efficiency is often opposed by constant reminders of the necessity to guarantee the independence of magistrates. This independence is considered the most important ruling posed by the Constitution to guarantee individual freedom but, translating it into reality it is the principle element of a more complex immunization strategy put into place to oppose change.

Making the justice system more efficient with the knowledge that even justice is a stimulus factor for the economy and, moreover, can contribute to leading the country out of this crisis does not undermine the independence of the magistrate. On the contrary, the independence of the magistrate is reserved for exercising its function, but the magistrature must also understand that it is part of a complex organization, whose rules of efficiency must be toughened and made binding.

In the countries in which the managerialization process of the justice system is more evolved, substantial compatibility between independence and accountability has been established. Both, in fact, represent fundamental presuppositions of the public action of Judicial Administrations, in view of safeguarding collective interests.

Reducing the influx of judicial demand, increasing the adaptability of the judicial instruments and increasing the efficiency of the judicial organization: these are the three guidelines that can inspire a period of reform to address the emergency that involves justice in a manner that is no less worrisome than the economy.

In the knowledge that courthouses are not temples for novices, but a crossroads of socialeconomic development of a country, it can be concluded that even a judicial office can no longer avoid the responsibility that is typical in every public institution of reporting the results achieved by reconciling a business approach with the provisions, the regulations and the directives that daily regulate judicial activity.

\section{Author details}

Ubaldo Comite

Address all correspondence to: ubaldo.comite@libero.it

University 'Giustino Fortunato', Benevento, Italy

\section{References}

[1] Comite U. (2010a). The efficiency, effectiveness and economy of the Italian Judicial System: The economic-business perspective. In 2010 International Conference on Public 
Administration ( $6^{\wedge}$ ICPA), "Public Administration Challenges and Opportunities: Serving Citizens in a Globalized World", Canberra, Australia, 22-24 September 2010 (Vol. I, pp. 337-348, ISBN 978-7-5647-0624-1).

[2] Kostoris R. (2003). Giustizia, garanzie ed efficienza: delicati equilibri e suggestioni. Diritto \& Giustizia no. 25. Milan: Giuffrè.

[3] Comite U. (2010b). Management and social balance in the Italian courts: Methods and operative proposals. In 2010 Oxford Business and Economics Conference (OBEC) Proceedings, St. Hugh's College- Oxford University, England, 28-30 June 2010 (ISBN 978-0-9742114-1-9).

[4] Alvino F., Lepore L. (2009). Court management: inquadramento dottrinale e strumenti operativi. Rome: Quaderni Monografici RIREA.

[5] Comite U. (2010c). The entrance of court management in the courts through the use of social balance: The Italian experience. In Global Conference on Business and Finance, online, 1931-0285 on CD, The Institute for Business and Finance Research, Hilo, HI, 3-6 January 2010, Keauhou Beach Resort, Kailua-Kona, Hawaii (Vol. 5, no. 1, ISSN 1941-9589).

[6] Caperchione E., Pezzani F. (Ed.). (2000). Responsabilità e trasparenza nella gestione dell'ente locale. Milan: Egea.

[7] Elder H. W. (1989). Trial and settlements in the criminal courts: An empirical analysis of dispositions and sentencing. The Journal of Legal Studies, Vol. XVIII, pp. 191-208, Chicago University Press.

[8] Anselmi L. (1995). Il processo di trasformazione della pubblica amministrazione. Turin: Giappichelli.

[9] Borgonovi E. (2005). Principi e sistemi aziendali per le amministrazioni pubbliche. Milan: Egea.

[10] Cavazzoni G. (2004). Il sistema del controllo di gestione. Strumenti per le decisioni operative aziendali. Turin: Giappichelli.

[11] Anselmi L. (Ed.). (2005). Principi e metodologie economico-aziendali per gli enti locali. Milan: Giuffrè.

[12] Hinna L. (Ed.). (2008). Appunti di Economia Aziendale. Padua: Cedam.

[13] Comite U. (2009). Business economy profiles of financial difficulties in local corporation: From default to financial renewal. Journal of International Finance and Economic (JIFE), Vol. 9, number 1, pp. 66-76.

[14] D'Alessio L. et al. (2008). Gruppo di studio e attenzione dell'Accademia Italiana di Economia Aziendale. In Innovazione e Accountability nella Amministrazione pubblica. I drivers del cambiamento. Rome. 
[15] Alford J. (1993). Towards a new public management model: Beyond managerialism and its critics. American Journal of Public Administration, Vol. 52, Issue 2. pp. 135-148

[16] Farneti G. (2004). Ragioneria Pubblica. Il nuovo sistema informativo delle aziende pubbliche. Milan: F. Angeli.

[17] Borgonovi E., Fattore G., Longo G. (2009). Management delle istituzioni pubbliche. Milan: Egea.

[18] Persiani N. (2002). Modelli di programmazione e sistemi di controllo interno nella pubblica amministrazione. Milan: F. Angeli.

[19] Sforza V. (2005). L'economia delle aziende sanitarie pubbliche. Logiche di gestione e strumenti di analisi dei risultati aziendali. Padua: Cedam.

[20] Comite U. (2009). Creazione di valore e sussidiarietà nell'amministrazione pubblica: un approccio economico-aziendale. In G.P. Calabrò (Ed.). La nozione di sussidiarietà tra teoria e prassi. Naples: Edizioni Scientifiche Italiane.

[21] Moore M. H. (2003). La creazione di valore pubblico. La gestione strategica nella pubblica amministrazione. Milan: Guerini e associati.

[22] Bertocchi M., Bisio L. (2005). Bilancio sociale: dalla rendicontazione al dialogo. "Il Sole 24 Ore", Guida agli Enti Locali no. 43. Milan.

[23] De Matteis F. (2011). Il bilancio per il cittadino negli enti locali. Padua: Cedam.

[24] Steccolini I. (2004). Accountability a sistemi informativi negli enti locali. Turin: Giappichelli. 